\title{
FUNGSI MASJID BERSEJARAH LUAR BATANG, JAKARTA UTARA, DAN PENGARUHNYA TERHADAP POLA PERMUKIMAN DI SEKITARNYA
}

\author{
Ashadi $^{1}$, Anisa $^{2}$, Ratna Dewi Nur'aini ${ }^{3}$ \\ 1,2,3Program Studi Arsitektur Fakultas Teknik Universitas Muhammadiyah Jakarta \\ Cempaka Putih Tengah 27 Jakarta Pusat 10510 \\ ashadi@ftumj.ac.id, anisa@ftumj.ac.id, ratnadewina@ftumj.ac.id
}

\begin{abstract}
ABSTRAK. Fungsi atau aktivitas yang terjadi pada suatu bangunan bersejarah akan mempengaruhi lingkungan sekitarnya. Penelitian ini mengamati aktivitas yang dilakukan pada bangunan bersejarah Masjid Luar Batang, Jakarta Utara, dan melihat pengaruhnya terhadap permukiman yang terbentuk di sekitarnya. Tujuan dari penelitian ini adalah untuk mendapatkan kesimpulan mengenai pengaruh dari aktivitas masjid terhadap permukiman yang ada di sekitarnya. Penelitian dilakukan di permukiman sekitar Masjid Luar Batang Jakarta Utara. Metode penelitian menggunakan deskriptif kualitatif dengan sampel diambil secara purposif. Aktivitas yang diamati adalah aktivitas rutin pada bangunan bersejarah yang meliputi aktivitas harian, mingguan, bulanan dan tahunan. Kesimpulan yang didapatkan dari penelitian ini adalah bentuk permukiman yang terkait erat dengan bangunan bersejarah, Masjid Luar Batang. Jalur jalan besar dan permukiman yang padat terjadi pada jalur utama menuju masjid Luar Batang. Dalam konteks lingkungan permukiman yang padat, ruang terbuka di sekitar masjid Luar Batang menjadi ruang publik yang banyak bermanfaat bagi permukiman sekitarnya.
\end{abstract}

Kata kunci : bangunan bersejarah, fungsi, masjid Luar Batang, permukiman.

ABSTRACT. Functions or activities that occur within a historic building will affect the surrounding environment. This study looked at the activities undertaken in the historic buildings LuarBatang Mosque, North Jakarta, and saw its influence on the settlements that formed around it. The purpose of this research is to get a conclusion about the effect of the mosque activitiesand its influence on settlements around it. The study was conducted in a settlement around the LuarBatang Mosque, North Jakarta. The research method using descriptive qualitative with the sample taken by purposive sampling. Activities observed are regular activities in historic buildings which include daily, weekly, monthly and yearly activities. The conclusion of this research is the form of settlement that is closely related to the historical building, the mosque of Luar Batang. Major roads and dense settlements occur on the main route to the LuarBatang Mosque. In the context of a dense residential neighborhood, open space around the LuarBatang mosque becomes a public space that is become a great use to the surrounding settlements.

Keywords: historic building, function, LuarBatang mosque, settlement.

\section{PENDAHULUAN}

Fungsi dan bentuk merupakan unsur-unsur penting dalam arsitektur. Dalam periode arsitektur modern, yang dinamakan fungsi adalah aktivitas yang dilakukan oleh manusia di dalam suatu ruang tiga dimensional $[1,2]$. Wadah yang berupa ruang tiga dimensional yang menampung kegiatan tersebut dinamakan bentuk. Dalam penelitian ini, yang dimaksud dengan fungsi adalah seluruh aktivitas yang dilakukan oleh masyarakat pendukung keberadaan masjid Luar Batang, Jakarta Utara, dan yang dimaksud dengan bentuk adalah pola permukiman di sekitar masjid tersebut.
Hal yang menarik, yaitu relasi fungsi-bentuk yang ingin diketahui bukan relasi fungsi masjid dengan bentuk masjid sebagaimana lazimnya penelitian arsitektur [3], melainkan relasi fungsi masjid dengan bentuk pola permukiman di sekitarnya. Premis penelitian ini bahwa fungsi masjid bersejarah Luar Batang, Jakarta Utara, memiliki pengaruh terhadap pola permukiman di sekitarnya. Keterpengaruhan ini didasarkan pada faktor kesejarahan bangunan masjid dan kampung Luar Batang.

Bangunan bersejarah masjid Luar Batang, Jakarta Utara, tidak bisa dipandang sama dengan bangunan masjid lainnya karena ada nilai-nilai sejarah yang terkandung di dalamnya. Aktivitas-aktivitas yang terjadi pada 
bangunan masjid bersejarah Luar Batang pun tidak selalu sama dengan bangunan masjidmasjid lainnya.

Hal inilah yang menjadi latar belakang perlunya dilakukan penelitian tentang pengaruhfungsi atau aktivitas masjid bersejarah Luar Batang, Jakarta Utara, terhadap pola permukiman di sekitarnya.

Masjid Luar Batang terletak di Kampung Luar Batang, Kelurahan Penjaringan, Kecamatan Penjaringan, Kodya Jakarta Utara. Masjid ini merupakan salah satu masjid tua bersejarah, yang kelahirannya berbarengan dengan lahirnya kota Batavia atau Jakarta. Kota Batavia atau Kota Tua Jakarta, selain masjid Luar Batang, juga memiliki beberapa masjid bersejarah, yaitu masjid Bandan, masjid Mangga Dua, masjid AIMansyur, masjid Annawir, masjid Kampung Baru, masjid Angke, dan masjid Tambora. Keunikan masjid Luar Batang dibandingkan dengan masjid-masjid bersejarah lainnya, yaitu, pertama lokasinya persis di mulut pelabuhan Sunda Kelapa, sebuah pelabuhan penting pada masa lalu, dan kedua, masjid ini menjadi keramat oleh adanya makam Habib Husein bin Abubakar Alaydrus.

Kampung Luar Batang merupakan kampung kota yang memiliki nilai sejarah dan merupakan bagian dari kota tua Jakarta. Kampung Luar Batang dilindungi oleh undangundang untuk dijaga kelestariannya dan mendapatkan hak konservasi. [4,5]

Kampung Luar Batang memiliki luas sekitar $131.500 \mathrm{~m}^{2}$ dan bersebelahan dengan kawasan Pasar Ikan (lama; sekarang dikenal dengan kampung Akuarium) yang memiliki luas sekitar $34.505 \mathrm{~m}^{2}$. Secara administratif Luar Batang terdiri dari $36 \mathrm{RT}$ dan $3 \mathrm{RW}$. [6].

Aktivitas yang terjadi pada masjid Luar Batang dapat diamati berdasarkan aktivitas yang dilakukan harian, mingguan, bulanan dan tahunan. Misalnya aktivitas sholat lima waktu, sholatdua hari raya idul fitri dan idul adha, perayaan hari-hari besar Islam dan aktivitas ziarah makam habib Husein bin Abu Bakar Alaydrus.

Hal yang menarik adalah masjid Luar Batang saat ini terletak di sekitar lingkungan yang padat. Pada lingkungan ini minim adanya ruang publik yang bisa digunakan untuk beraktivitas sehingga ruang terbuka yang ada di sekitar masjid luar Batang selain digunakan untuk parkir juga digunakan untuk beraktivitas penduduk sekitar.

Berdasarkan latar belakang tersebut maka penelitian ini bertujuan untuk : (1) mengidentifikasi dan mengetahui fungsi atau aktivitas yang dilakukan oleh masyarakat pendukung keberadaan masjid Luar batang; dan (2) mengetahui pengaruh fungsi atau aktivitas masjid Luar Batang terhadap permukiman di sekitarnya.

\section{METODE PENELITIAN}

Penelitian ini menggunakan metode deskriptif interpretatif. Pendataan lapangan dilakukan dengan cara, pertama, observasi subjek studi, yaitu, aktivitas masyarakat pendukung masjid Luar Batang dan bentuk-bentuk rumah permukiman Luar Batang, dan kedua, yaitu kegiatan wawancara kepada pengurus BKM dan orang-orang yang memiliki pemahaman terhadap masjid Luar Batang dan lingkungan permukiman di sekitarnya.

Dalam rangka mencapai tujuan penelitian, maka dilakukan langkah-langkah sebagai berikut : (1) merekam dan mendeskripsikan seluruh fungsi masjid; (2) merekam dan mendeskripsikan bentuk tampilan dan orientasi deretan rumah-rumah tinggal, jalan lingkungan, perparkiran, dan ruang terbuka sebagai unsur-unsur utama pembentuk pola permukiman; (3)mengaitkan atau merelasikan fungsi-fungsi masjid dengan bentuk pola permukiman; dan (4) menginterpretasi relasi tersebut untuk menarik konklusi keterpengaruhan. Langkah-langkah tersebut sekaligus menjadi bagian penting dari kerangka penelitian terbangun. (Gambar 1).

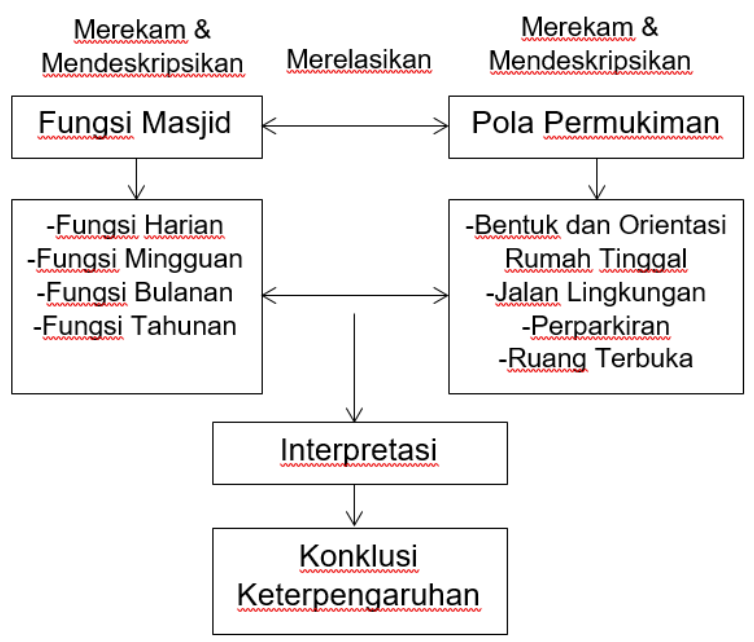

Gambar 1. Kerangka Penelitian 


\section{HASIL DAN PEMBAHASAN}

\section{Kampung dan Masjid Luar Batang}

Kampung Luar Batang berlokasi di Kelurahan Penjaringan, Kecamatan Penjaringan, Kodya Jakarta Utara. Kampung Luar Batang menjadi terkenal dan banyak dikunjungi peziarah maupun wisatawan karena keberadaan masjid Bersejarah yaitu Masjid Luar Batang. Lokasi kampung Luar Batang, di sebelah timur dan selatan dibatasi oleh terusan Laut Jawa, di utara oleh pergudangan, dan di barat oleh jalan raya Gedong Panjang dan jalan Muara Baru. Berdasarkan observasi lapangan dan wawancara didapatkan data Kampung Luar Batang, yaitu terdiri dari $3 \mathrm{RW}$ dan $36 \mathrm{RT}$. RW 01 memiliki 11 RT dan $700 \mathrm{KK}$, RW 02 memiliki 12 RT dan $870 \mathrm{KK}, \mathrm{RW} 03$ memiliki 14 RT dan 1000 KK. Masjid Luar Batang ada di RW 03. (Gambar 2 dan Gambar 3).

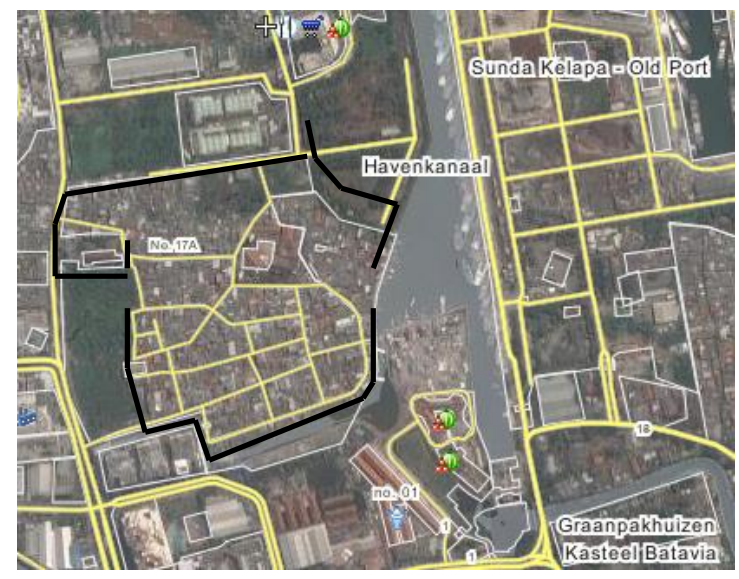

Gambar 2. Peta wilayah Kampung Luar Batang, Jakarta Utara (garis tebal hitam)

(Sumber : Wikimapia, 2017)

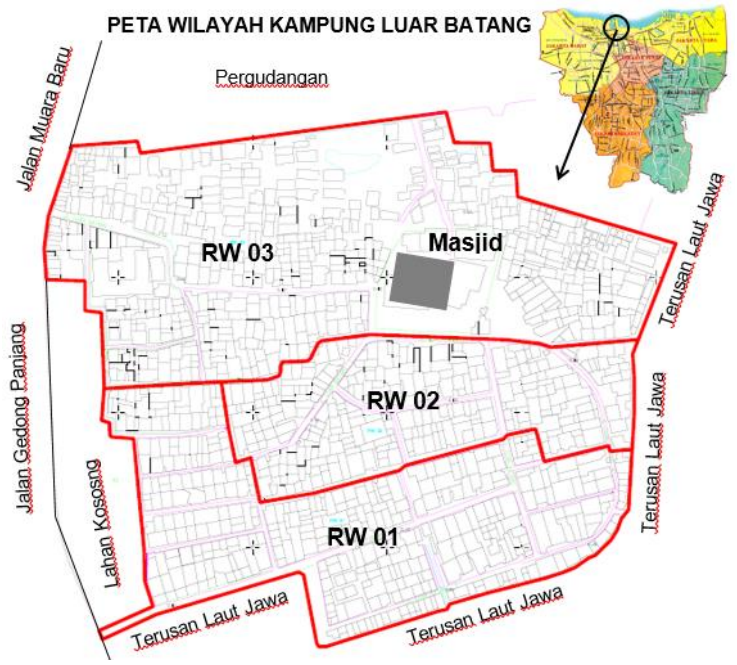

Gambar 3. Pembagian wilayah tingkat RW Kampung Luar Batang

(Sumber : Hasil Observasi, 2017)
Masjid Luar Batang termasuk masjid terkenal di Batavia karena keramat Sayid Husein bin Abu Bakar bin Abdillah Alaydrus (wafat 1756). Masjid keramat ini menarik banyak peziarah. Masjid ini terletak di sebelah utara tembok kota lama, di daerah yang sesudah pertengahan abad ke-17 diuruk dan baru boleh dihuni oleh orang Jawa dari Cirebon sejak 1730. Mereka bertugas membersihkan mulut kali Ciliwung dari lumpur, supaya kapal bisa sampai ke Pasar Ikan yang letaknya tidak jauh dari mesjid ini. [7]

Penduduk kampung Luar Batang bersifatmultietnis, dari sejak dulu hingga sekarang. Penduduk setempat menghubungkan nama Luar Batang dengan legenda Al-Habib Husein: "Jenazah Al-Habib Husein diusung dalam kurung batang ('keranda') ditandu ke kuburan Tanah Abang seperti seharusnya, namun sesampainya dikuburan, jenazah Habib tiada lagi dan ternyata sudah kembali ke rumahnya. Hal ini terjadi berulang kali. Maka disepakati, bahwa jenazah ini dikebumikan di rumahnya yang karenanya kemudian disebut Luar Batang". $[8,9]$.

Kampung Luar Batang merupakan pemukiman tertua di Jakarta, dibangun sekitar tahun 1630 . Padaawalnya pemukiman ini lahir untuk memenuhi kebutuhan tempat tinggal yang dekat dengan tempat bekerja, yakni Pelabuhan Sunda Kelapa.Keunikan Kampung Luar Batang adalah karena dulunya masih dikelilingi rawa, untuk masuk harus menggunakan sampan. Akses menuju ke pasar ikan pun memerlukan sampan. Kini telah ada aksesjalan darat dari Jalan Muara Baru Raya. Kondisi kampung yang sangat dekat dengan laut dan memiliki permukaan tanah yang lebih rendah menyebabkan seringnya terjadi banjir rob. Drainase juga buruk karena tidak bisa mengalir dengan lancar. Pada tahun 2015, jalan-jalan utama di dalam kampung diperbaiki dan ditinggikan setinggi $80 \mathrm{~cm}$. Akibatnya, rumah-rumah lama berada di bawahketinggian/permukaan jalan, sehingga kalau hujan turun keadaan makin parah, dan bisa dipastikanakan banjir.[10].

Kampung Luar Batang terletak di Kelurahan Penjaringan Kecamatan Penjaringan. Jumlah penduduk di Kelurahan Penjaringan pada tahun 2015 sebanyak 118.010 jiwa dengan perincian 62.485 penduduk laki-laki dan 55.525 penduduk perempuan. Rata-rata penghuni kampung mempunyai pekerjaan buruh dan berdagang, termasuk berdagang di sekitar permukimannya dan sekitar Masjid 
Luar Batang. Rata-rata rumah mempunyai ketinggian 2 lantai dan dihuni oleh 3-5 orang. Namun ada juga rumah yang dihuni oleh lebih dari 10 orang. $[11,12,13]$.

\section{Perekaman dan Pendeskripsian Fungsi Masjid Bersejarah Kampung Luar Batang}

Perekaman dan pendeskripsian fungsi masjid Luar Batang meliputi fungsi harian, mingguan, bulanan, dan tahunan. Fungsi atau aktivitas harian yaitu meliputi : (1) shalat wajib lima waktu secara berjamaah, yang terdiri dari shalat Subuh, Dhuhur, Ashar, Maghrib, dan Isya, dan (2) ziarah makam Habib Husein. Pada hari-hari biasa jumlah jamaah shalat lima waktu berkisar $152-266$ orang (4 - 7 shaf). Khusus setiap malam Jumat, jumlah jamaah shalat Maghrib dan Isya sekitar 380 608orang (10 - 16 shaf). Pada setiap acara haul yang jatuh pada minggu terakhir bulan Syawal dan peringatan Maulid pada minggu terakhir bulan Rabiul Awwal, shalat Dhuhur diikuti oleh sekitar 10.000 - 12.000 orang (tempat shalat : ruang utama hingga ke halaman masjid depan, kanan, kiri dan sebagian teras ruang-ruang kantor takmir masjid). Fungsi atau aktivitas ziarah ke makam Habib Husein yang letaknya di sebelah serambi masjid, setiap harinya melibatkan jumlah peziarah berkisar 100 - 500 orang. Berdasarkan hasil wawancara dengan informan 1 dan 2, pada umumnya para peziarah datang dari daerah-daerah di wilayah Jadebotabek, Banten, dan Jawa Barat.

Fungsi atau aktivitas mingguan masjid Luar Batang yaitu meliputi : (1) shalat Jumat; (2) ziarah makam malam Jumat; dan (3) pasar (bazar) malam Jumat. Shalat Jumat dihadiri sekitar $1.300-1.600$ jamaah (tempat shalat : ruang utama hingga serambi depan, kanan dan kiri). Kegiatan ziarah pada setiap malam Jumat mengalami peningkatan jumlah peziarah dibandingkan dengan hari-hari biasa, yaitu jumlahnya sekitar $1.000-3.000$ orang. Kegiatan mingguan yang menyedot anemo masyarakat setempat adalah pasar (bazar) yang diadakan setiap malam Jumat. Lapaklapak disiapkan sejak waktu selepas shalat Ashar.

Menurut penuturan informan 3 dan 4, para pedagang kaki lima dari berbagai wilayah di Jakarta ikut serta dalam pasar malam Jumat ini, seperti pedagang kali lima dari Pasar Minggu, Senen, Tanah Abang, dan Muara Angke. Jumlah mereka mencapai $60 \%$ dari keseluruhan pedagang pasar malam Jumat. Yang $40 \%$ lagi adalah warga setempat, kampung Luar Batang, yang menjadikan rumahnya sebagai tempat dagang. Setiap lapak dikenakan biaya lampu penerangan $\mathrm{Rp}$. 5.000 dan restribusi berkisar antara $\mathrm{Rp}$. $10.000-25.000$.

Pasar malam Jumat menempati areal ruas jalan Luar Batang 1 dan 5, serta sebagian ruas jalan Luar Batang 7. Dari sekian ruas jalan lingkungan di kampung Luar Batang, memang hanya ada 4 ruas jalan yang sedikit agak lebar. Satu lagi jalan yang dimaksud adalah jalan Luar Batang 2. Karena letaknya agak jauh dari kompleks masjid, maka jalan Luar Batang 2 tidak digunakan untuk pasar malam Jumat. Suasana ramai terlihat di ruas jalan yang letaknya dekat dengan masjid. Sehingga dapat diduga bahwa memang kegiatan pasar malam Jumat pusatnya ada di sekitar kompleks masjid tua Luar Batang. Hampir semua barang ada di pasar malam Jumat, selain tentu saja warung makan dadakan. Barang-barang seperti pakaian, sepatu, jam tangan, asesories wanita, kopiyah (penutup kepala), alat-alat pertukangan, cicin, batu akik, dan tidak ketinggalan minyak wangi, dapat dijumpai di pasar malam Jumat. (Gambar 4).

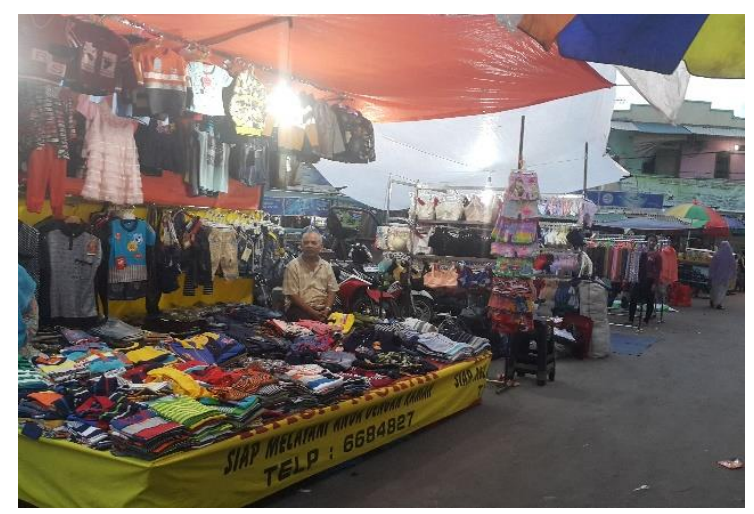

Gambar 4. Suasana pasar malam Jumat di sekitar Kompleks Masjid Luar Batang (Sumber : Hasil Observasi, 2017)

Fungsi atau aktivitas bulanan masjid Luar Batang tidak ada. Biasanya pada masjidmasjid bersejarah dan keramat seperti masjidmesjid Walisanga setiap bulannya (tepatnya 35 hari berdasarkan hari pasaran Jawa), yang jatuh pada malam Jumat Kliwon atau sebagian masjid pada Jumat Legi, peziarah makam lebih banyak jumlahnya dibandingkan dengan hari-hari biasa atau malam Jumat biasa [14]. Pada masjid Luar Batang setiap malam Jumat (tidak hanya malam Jumat Kliwon atau Jumat Legi saja) jumlah peziarah meningkat dibandingkan hari-hari biasa.

Fungsi atau aktivitas tahunan masjid Luar Batang yaitu meliputi : (1) shalat Teraweh di 
bulan Ramadhan, shalat Hari Raya Idul Fitri dan Idul Adha; (2) haul Habib Husein, peringatan Maulid Nabi Muhammad SAW, Nuzulul Qur'an, dan akhir ziarah. Menurut cerita informan 1, kegiatan shalat Teraweh di bulan Ramadhan, tidak jauh berbeda dengan keadaan pada masjid-masjid lainnya. Pada awal bulan jamaah penuh, namun mulai pertengahan hingga akhir bulan mengalami penurunan. Kegiatan shalat Idul Fitri dan Idul Adha diikuti oleh sekitar $6.000-8.000$ jamaah, yang memenuhi masjid dan halamannya.

Pada kegiatan haul, peringatan Maulid, Nuzulul Qur'an, dan akhir ziarah, jamaah yang ikut hadir berjumlah hampir sama, kecuali pada peringatan Nuzulul Qur'an yang diselenggarakan setiap tanggal 17 bulan Ramadhan. Jumlah jamaah pada ketiga kegiatan tersebut berjumlah sekitar 25.000 30.000 orang. Para pengunjung tidak hanya memenuhi kompleks masjid (ruang utama, serambi, teras ruang kantor, dan halaman) tapi juga areal parkir dan ruas-ruas jalan terutama yang dekat dengan kompleks masjid. Kegiatan dimulai jam 08.00 hingga waktu Dhuhur. Dari jumlah yang hadir dalam kegiatan tersebut, saat waktu shalat Dhuhur tiba, hanya sekitar seperempat sampai seperlimanya yang ikut shalat Dhuhur berjamaah, karena memang kompleks masjid tidak mencukupi untuk menampung jamaah seluruhnya. Menurut cerita informan 1, kegiatan peringatan Nuzulul Qur'an dilaksanakan pada malam hari, selepas shalat Isya, yang dihadiri sekitar $4.000-6.000$ jamaah. Kegiatan akhir ziarah diadakan pada tiga atau tujuh hari sebelum bulan Ramadhan. Dalam setiap kegiatan haul, peringatan Maulid, Nuzulul Qur'an, dan akhir ziarah, para jamaah yang hadir akan juga berziarah ke makam Habib Husein (Gambar 5).

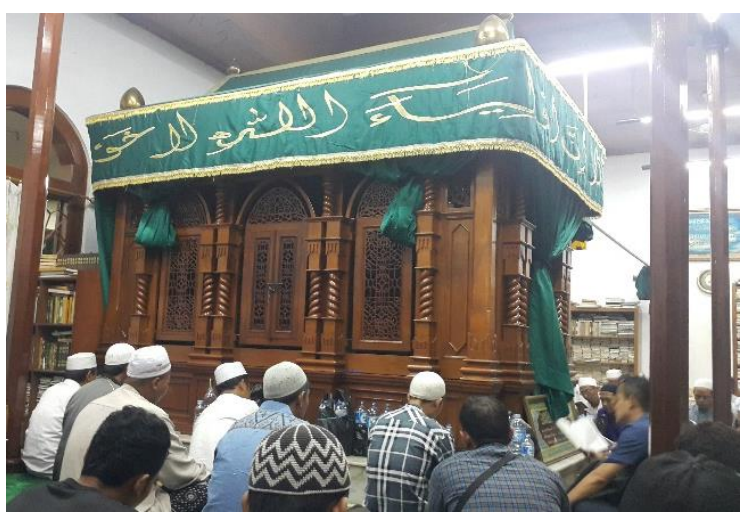

Gambar 5. Suasana ziarah di makam Habib Husein (Sumber : Hasil Observasi, 2017)

\section{Perekaman dan Pendeskripsian Bentuk Pola Permukiman Kampung Luar Batang}

Perekaman dan pendeskripsian bentuk pola permukiman kampung Luar Batang meliputi bentuk dan orientasi rumah, jalan lingkungan, perparkiran, dan ruang terbuka.

Berdasarkan observasi lapangan, jumlah seluruh bangunan rumah tinggal di ketiga RW adalah 1.085 rumah, yang terdiri atas 381 bangunan rumah berada di RW 01, 281 bangunan rumah berada di RW 02, dan 423 bangunan rumah berada di RW 03 . Sebagian besar rumah di kampung Luar Batang bertingkat atau terdiri atas dua lantai, meskipun ada juga yang tiga lantai, dan bahkan empat lantai. Semua rumah menghadap ke jalan lingkungan (jalan Luar Batang $1-9$ ), termasuk deretan rumah di tepi terusan Laut Jawa, baik di sebelah timur maupun selatan.

Sebagian rumah tinggal difungsikan juga untuk usaha warung atau jualan, terutama yang berada di sisi-sisi jalan Luar Batang 1, 2, 5, dan sebagian jalan Luar Batang 7. Hal ini bisa dilihat dari bentuk rumahnya yang penuh dengan barang dagangan pada bagian depannya. Tampak rumahnya seperti warung atau toko. Rumah-rumah yang berada di sisisisi jalan Luar Batang 1, 2, 5, dan sebagian 7, dan yang lokasinya tidak jauh dari kompleks masjid, secara fisik terlihat bangunan yang didominasi oleh dinding bata atau campuran dinding bata dengan kayu. Sedangkan rumahrumah yang lokasinya dekat dengan terusan Laut Jawa, baik di sisi timur maupun selatan, dan di dekat pergudangan, sebelah utara, bangunannya didominasi oleh material kayu. (Gambar 6 dan Gambar 7).

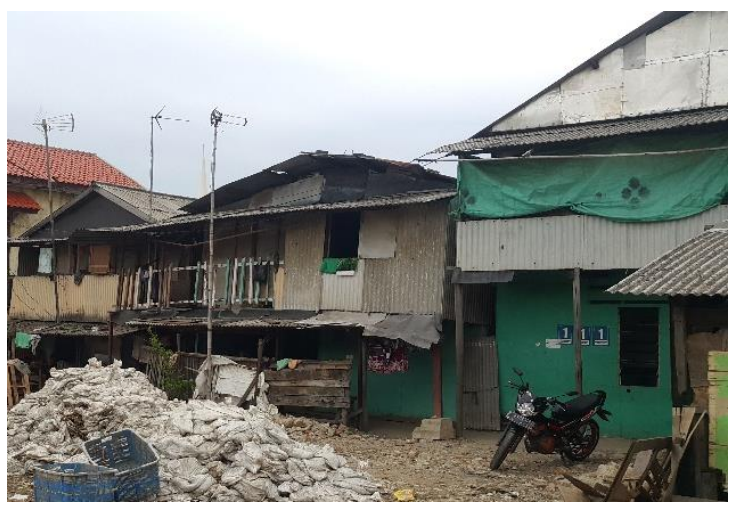

Gambar 6. Bangunan Rumah Tinggal berlokasi di dekat pergudangan, didominasi oleh material kayu (Sumber : Hasil Observasi, 2017) 


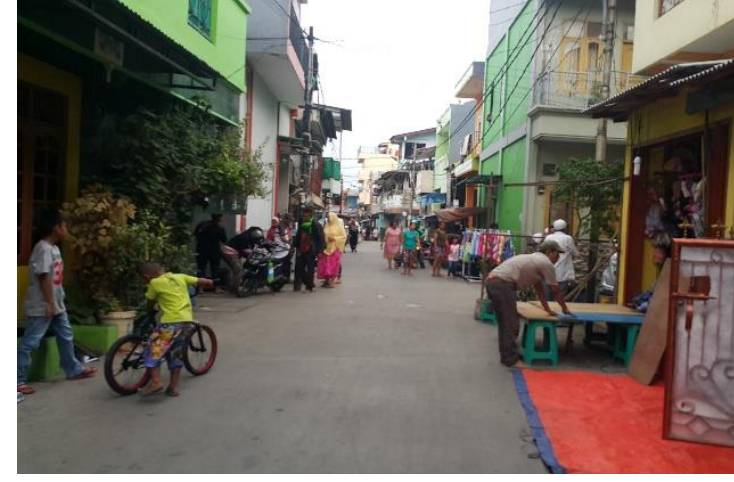

Gambar 7. Bangunan Rumah Tinggal berlokasi di jalan Luar Batang 5, didominasi oleh dinding bata (Sumber : Hasil Observasi, 2017)

Jalan lingkungan di kampung Luar Batang meliputi 9 jalan, yaitu jalan Luar Batang $1-9$, dengan lebar dan kualitas jalan yang tidak sama satu dengan lainnya (gambar 8).

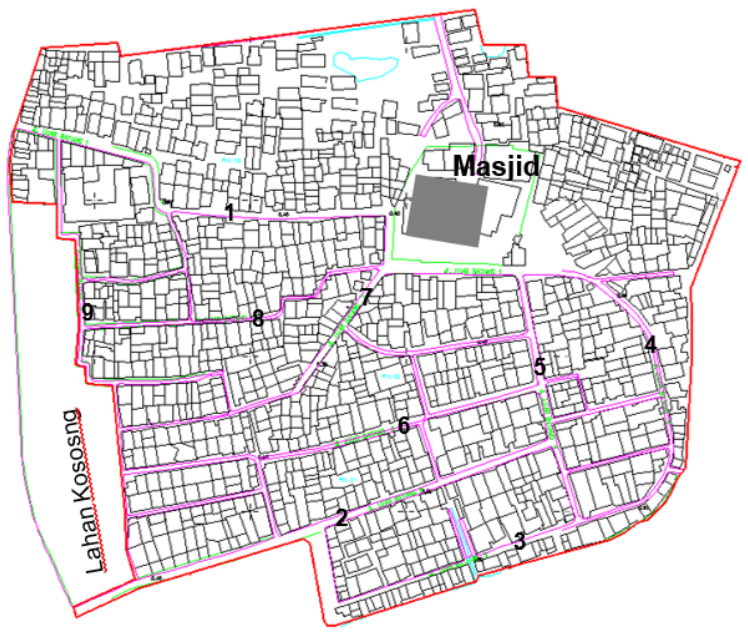

Gambar 8. Ruas Jalan Luar Batang 1 - 9

(Sumber : Hasil Observasi, 2017)

Jalan Luar Batang 1, lebarnya 4,5 meter, kondisi jalan beraspal. Jalan ini merupakan akses para pengunjung masjid Luar Batang dari arah jalan raya Muara Baru. Jalan Luar Batang 2, lebarnya 5,5 meter, kondisi jalan beraspal. Jalan ini merupakan akses para pengunjung masjid Luar Batang dari arah jalan raya Gedong Panjang. Jalan raya Muara Baru adalah perpanjangan jalan raya Gedong Panjang ke arah Utara. Jalan Luar Batang 3, lebarnya 2,75 meter, kondisi campuran batu dan plesteran. Ruas jalan ini berada sejajar dengan jalan Luar Batang 2 pada bagian paling selatan. Aksesnya harus melewati jalan Luar Batang 2. Jalan Luar Batang 4, lebarnya 2,75 meter, kondisinya campuran batu dan plesteran. Ruas jalan ini merupakan perpanjangan jalan Luar Batang 2 pada sisi timur, dan bentuknya melengkung. Jalan ini merupakan akses para pengunjung masjid Luar Batang dari arah kampung Akuarium dan museum Bahari, dengan menyeberangi terusan Laut Jawa. Jalan Luar Batang 5, lebarnya 4,5 meter, kondisinya beraspal. Jalan ini merupakan terusan jalan Luar Batang 2 menuju kompleks masjid. Jalan Luar Batang 6, lebarnya 2,5 meter, kondisi jalan berupa plesteran. Jalan Luar Batang 7, lebar ruas jalan yang dekat dengan masjid 3,25 meter, dan yang jauh dari masjid 2 meter. Kondisi jalan sebagian beraspal, sebagian berupa plesteran. Jalan Luar Batang 8, lebarnya 2 meter, kondisi jalan berupa pelesteran yang sebagiannya sudah aus. Jalan Luar Batang 9, lebarnya 2,5 meter, kondisi jalan berupa plesteran.

Area perparkiran kampung Luar Batang, dalam sehari-harinya adalah ruang terbuka di depan kompleks masjid Luar Batang. Kendaraan mobil kecil dan motor dapat diparkir di tempat ini. Dalam keadaan yang tidak biasa, seperti keadaan pada saat peringatan haul, Maulid, dan Akhir Ziarah, maka areal perparkiran bisa menggunakan lahan di samping pergudangan, di sebelah utara wilayah kampung Luar Batang, dan di ruas-ruas jalan Luar Batang, terutama jalan Luar Batang 1, 2, 5, dan 7. Untuk kendaraan bis biasanya parkir di sepanjang jalan raya Gedong Panjang dan area parkir Museum Bahari. Dari area parkir museum Bahari menuju kampung Luar Batang harus menyeberangi terusan Laut Jawa, dengan bantuan ojek perahu. Apabila jumlah para pengunjung membludak maka ruas-ruas jalan Luar Batang selain yang telah disebutkan dapat dipergunakan sebagai areal parkir kendaraan roda dua. (Gambar 9).

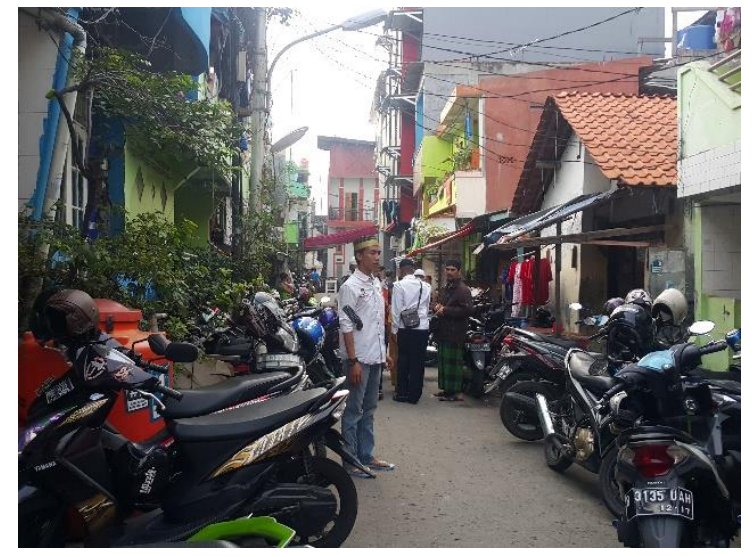

Gambar 9. Ruas Jalan Luar Batang 6 difungsikan sebagai Areal Parkir Sepeda Motor (Sumber : Hasil Observasi, 2017) 
Ruang terbuka di kampung Luar Batang lokasinya persis di depan kompleks masjid Luar Batang. Sehari-harinya ruang terbuka ini difungsikan sebagai areal parkir. Namun kadang-kadang juga digunakan sebagai tempat resepsi pernikahan, seperti yang terjadi baru-baru ini (gambar 10). Sebenarnya di sebelah utara kompleks masjid ada areal terbuka hijau, namun kondisinya seperti tanah lapang tidak bertuan, sebagian berair dan dipenuhi dengan tumbuhan ilalang.

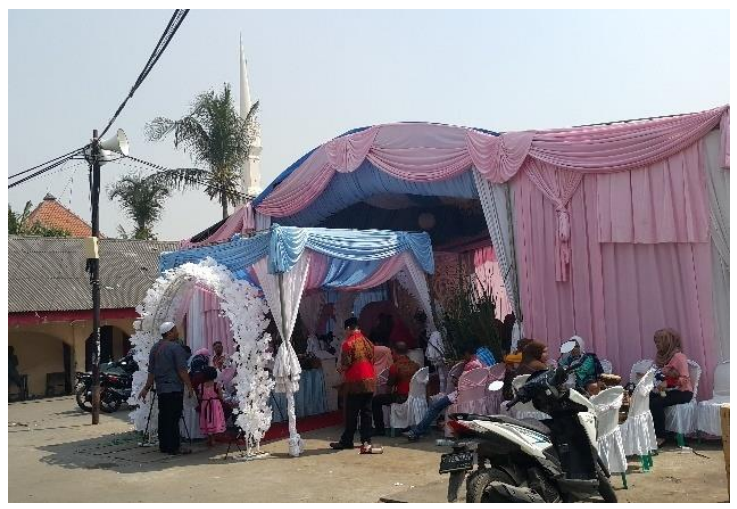

Gambar 10. Areal parkir digunakan untuk acara resepsi pernikahan

(Sumber : Hasil Observasi, 2017)

\section{Relasi dan Interpretasi}

Dalam bagian ini, fungsi masjid yang meliputi fungsi harian, mingguan, dan tahunan direlasikan atau dihubungkan dengan pola permukiman kampung Luar Batang yang meliputi bentuk dan orientasi rumah, jalan lingkungan, perparkiran, dan ruang terbuka, kemudian relasi tersebut diinterpretasikan.

Dari rekaman dan deskripsi di atas, maka dapat dijelaskan relasi-relasi yang terjadi. Fungsi harian masjid yang berupa kegiatan shalat Lima Waktu berjamaah tidak memiliki relasi dengan bentuk dan orientasi rumah, jalan lingkungan, perparkiran, dan ruang terbuka, karena jamaahnya adalah orangorang setempat. Fungsi harian yang berupa kegiatan ziarah ke makam memiliki relasi dengan perparkiran dan ruang terbuka, karena peziarah datang dari luar wilayah kampung Luar Batang.

Fungsi mingguan masjid yang berupa shalat Jumat, seperti pada kegiatan shalat Lima Waktu, jamaahnya berasal dari lingkungan setempat, sehingga tidak memiliki relasi dengan bentuk dan orientasi rumah, jalan lingkungan, perparkiran, dan ruang terbuka. Fungsi mingguan yang berupa kegiatan ziarah ke makam memiliki relasi dengan perparkiran dan ruang terbuka, karena peziarah datang dari luar. Fungsi mingguan yang berupa kegiatan pasar malam Jumat memiliki relasi dengan bentuk dan orientasi rumah, jalan lingkungan, perparkiran, dan ruang terbuka. Relasi dengan bentuk dan orientasi rumah diperlihatkan pada bagian depan rumah yang pada umumnya dibuat toko atau warung yang menghadap ke depan, ke jalan lingkungan yang digunakan sebagai areal pasar malam Jumat. Relasi dengan jalan lingkungan diperlihatkan oleh berubahnya fungsi ruas jalan lingkungan menjadi areal pasar malam. Relasi dengan perparkiran diperlihatkan oleh berubahnya fungsi jalan lingkungan menjadi areal parkir kendaraan bermotor roda dua. Relasi dengan ruang terbuka diperlihatkan oleh berubahnya fungsi ruang terbuka menjadi areal pasar.

Fungsi tahunan masjid yang berupa shalat Teraweh, Idul Fitri, dan Idul Adha, seperti pada kegiatan shalat Jumat dan Lima Waktu, jamaahnya berasal dari lingkungan setempat, sehingga tidak memiliki relasi dengan bentuk dan orientasi rumah, jalan lingkungan, perparkiran, dan ruang terbuka. Fungsi tahunan yang berupa kegiatan haul, Maulid, dan Akhir Ziarah memiliki relasi dengan bentuk dan orientasi rumah, jalan lingkungan, perparkiran, dan ruang terbuka. Kehadiran puluhan ribu jamaah di kampung Luar Batang yang begitu padat selama hampir enam jam lamanya (jam 08.00 - 12.00) jelas berdampak ekonomi pada masyarakat kampung Luar Batang. Sehingga kegiatan tahunan ini memiliki relasi pada bentuk dan orientasi rumah, jalan lingkungan, perparkiran, dan ruang terbuka. (Gambar 11)

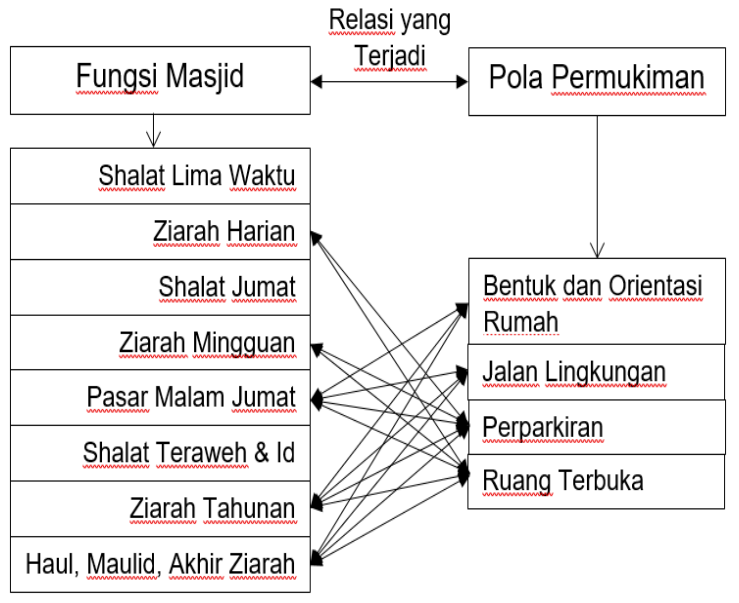

Gambar 11. Gambar diagram relasi antara fungsi masjid dan pola permukiman (Sumber : Hasil Interpretasi, 2017) 


\section{Konstruksi Hasil Interpretasi : Membaca Keterpengaruhan}

Keterpengaruhan fungsi masjid terhadap pola permukiman kampung Luar Batang dibaca berdasarkan ada atau tidaknya relasi antara fungsi-fungsi masjid dengan pola permukiman di sekitarnya (Gambar 11).

Fungsi-fungsi atau aktivitas-aktivitas yang terjadi di masjid Luar Batang, terutama fungsi ziarah, haul, maulid, dan akhir ziarah, serta fungsi pasar malam atau bazar yang menyertainya, mempunyai pengaruh terhadap pola permukimandi sekitarnya. Kondisi lingkungan sekitar Masjid yang mayoritas berupa permukiman berkepadatan tinggi dan jalan-jalan sempit turut merespon keramaian yang terjadi berkaitan dengan fungsi-fungsi masjid. Bagi warga sekitarnya yang mayoritas beragama Islam, masjid Luar Batang dijadikan pusat kegiatan keagamaan tidak hanya Shalat saja, tapi juga menjadi tempat kegiatankegiatan lain yang ikut mendorong usahausaha ekonomis komunitas muslim kampung Luar Batang.

Tingginya intensitas aktivitas ziarah ke makam Habib Husein yang lokasinya di serambi masjid Luar Batang, menimbulkan terjadinya aktivitas lain di sekitar masjid. Aktivitas yang dimaksud adalah aktivitas yang bernilai komersial seperti adanya bazar dan pasar malam Jumat, munculnya warung-warung menjual minuman dan makanan, penjual perlengkapan ziarah (kembang payung, kemenyan, air), warung-warung kelontong, dan persewaan KM /WC.

Ramainya masjid Luar Batang ini kemudian dimanfaatkan oleh pedagang dadakan atau pedagang tetap untuk mengadakan bazar dan pasar malam Jumat yang lokasinya tidak hanya di halaman ruang terbuka sekitar masjid saja namun juga di sepanjang jalan menuju ke masjid Luar Batang. Jadi kegiatan komersial ini terjadi di jalan-jalan menuju masjid Luar Batang, tidak hanya jalan utama yang besar saja namun juga ke jalan-jalan kecil yang biasa dilewati peziarah.

Pedagang yang ada di sekitar jalan menuju masjid Luar Batang menjual dagangannya dengan beberapa cara. Ada yang menggunakan gerobak dan berlokasi di tepi jalan (menggunakan bahu jalan) sehingga menimbulkan kemacetan. Namun ada pula yang berjualan dengan membuka warung di halaman rumahnya. Sehingga tidak ada batas antara rumah dengan jalan.
Aktivitas komersial tersebut merubah bentuk permukimannya. Perubahan yang terjadi antara lain terlihat dengan semakin padatnya lingkungan terutama pada jalan-jalan menuju masjid Luar Batang dengan keberadaan para pedagang. Selain itu juga mulai berkurangnya privasi pada rumah tinggal disebabkan banyak rumah yang kemudian difungsikan juga untuk aktivitas komersil seperti menyewakan $\mathrm{KM} / \mathrm{WC}$, menyewakan sebagian ruang untuk istirahat peziarah, dan membuka toko makanan/warung makan.

Masyarakat Luar Batang berdagang dengan sarana yang beragam.Ada yang menggelar barang dagangan di meja, digantung pada dinding rumah, teritis atap, pagar, tangga atau di atas riool yang ditutup papan. Karena kegiatan berdagang dilakukan semalaman maka pedagang yang menggunakan lahan umum atau menggunakan teras rumah orang lain secara sukarela member kompensasi dana untuk membayar listrik yang digunakan.

Penduduk setempatmemanfaatkan situasi ramainya aktivitas di masjid Luar Batang untuk menambah penghasilan, sebagai momen yang ditunggu di setiap kegiatan bazar dan pasar malam Jumat. Pihak RW setempat mendapat keuntungan pula melalui tarikan sewa ruang sebagai kompensasi untuk biaya kebersihan lingkungan. Di beberapa pintu masuk menuju kampung sejumlah penduduk secara terorganisir menarik retribusi untuk perbaikan lingkungan selain untuk menambah penghasilannya sendiri. [15,16].

Pedagang yang berjualan di sekitar masjid dan jalan-jalan menuju masjid tidak hanya penduduk asli/sekitar Masjid saja namun juga pedagang pendatang. Bedanya adalah pedagang pendatang lebih mendominasi.

\section{KESIMPULAN}

Kesimpulan yang didapatkan dari penelitian ini adalah ada pengaruh yang ditimbulkan oleh aktivitas pada masjid Luar Batang dengan permukiman yang ada di sekitarnya. Adanya keterpengaruhan ini ditunjukkan oleh adanya relasi atau kaitan antara fungsi masjid dengan pola permukiman kampung Luar Batang. Fungsi masjid yang berelasi meliputi fungsi atau aktivitas ziarah, pasar malam Jumat, dan bazar-bazar yang menyertai kegiatan haul, maulid, dan akhir ziarah. Bentuk pola permukiman yang berelasi meliputi bentuk dan orientasi rumah, jalan lingkungan, perparkiran, dan ruang terbuka. 
Keterpengaruhan, secara kasat mata, ditunjukkan antara lain oleh banyaknya pedagang yang berjualan baik di pelataran masjid (untuk menyediakan keperluan peziarah) dan juga pada jalan-jalan yang ada di sekitar dan menuju ke Masjid. Pengaruh yang lain terhadap permukimannya dapat dilihat pada ukuran jalur jalan dan permukimannya, dimana jalur jalan besar dan permukiman yang padat terjadi pada jalur utama menuju masjid Luar Batang. Dalam konteks lingkungan permukiman yang padat, ruang terbuka di sekitar masjid Luar Batang menjadi ruang publik yang banyak bermanfaat bagi permukiman sekitarnya.

\section{UCAPAN TERIMA KASIH}

Tulisan ini merupakan bagian dari penelitian dengan judul Model Penataan Hunian di Sekitar Bangunan Bersejarah dalam Rangka Peningkatan Potensi Kawasan Wisata. Kasus Studi Hunian di Sekitar Masjid Luar Batang yang dilakukan dengan sumber dana yang dari DRPM dengan SK Direktur Jenderal Penguatan Riset dan Pengembangan Nomor: 01/E3/KTP/2017 tanggal 6 Januari 2017.

\section{DAFTAR PUSTAKA}

[1] Adorno, Theodor W. (1997). Functionalism Today. Rethinking Architecture: A Reader in Cultural Theory. Leah, Neil (Ed.) London : Routledge.

[2] Heynen, Hilde. (1999). Architecture and Modernity. Massachusetts : MIT Press.

[3]Ashadi; Antariksa; Purnama Salura. (2015). Pengaruh Sinkretisme Agama IslamKejawen Pada Arsitektur Mesjid Menara Kudus. Jurnal Arsitektur NALARs Volume 14 No 2 Juli 2015

[4] Dinas Penataan dan Pengawasan Bangunan Propinsi DKI Jakarta. (2004). Buku Petunjuk Membangun di Propinsi DKI Jakarta.

[5] Iskandaria, Harfa, Ispurwono Sumarno, Johan Silas. (2013). Peran Kampung Luar Batang Kecamatan Penjaringan Jakarta Utara Dalam Menunjang Konservasi Kota Tua. Arsitron Vol 4 No 1 Juni 2013.

[6] Kasman,Tamiya Miftahu Saada. (2016). Hubungan Karakteristik Penduduk dengan Pemilihan Ruang Publik di Kampung Luar Batang, Jakarta Utara. Prosiding Temu IImiah IPLBI 2016.

[7] Heuken SJ., Adolf. (2003). Mesjid-mesjid tua di Jakarta. Jakarta : Yayasan Cipta Loka Caraka
[8] Heuken SJ., Adolf. (2016). Tempat-Tempat Bersejarah di Jakarta. Jakarta : Yayasan Cipta Loka Caraka

[9] Sudarso, Yus. (1998). Sepintas Riwayat Shahibul Qutub Al-Habib Husein bin Abubakar Alaydrus.

[10] Padawangi, Rita, dkk. (2015). Kota Tua, Kota Vernakular : Identitas Budaya dalam Pusaka Keseharian Kota.

[11] Badan Pusat Statistik Jakarta Utara. https://jakutkota.bps.go.id/linktableDinamis /view/id/24

[12] Badan Pusat Statistik Jakarta Utara. https://jakutkota.bps.go.id/linktableDinamis /view/id/28

[13] Badan Pusat Statistik Jakarta Utara. https://jakutkota.bps.go.id/linktableDinamis /view/id/33

[14] Ashadi. (2016). Makna Sinkretisme Bentuk Pada Arsitektur Mesjid-Mesjid Walisanga.Disertasi. Program Studi Doktor Arsitektur Sekolah Pascasarjana Universitas Parahyangan.

[15]Puspitasari, Popi. (2009). Kontroversi Eksistensi Kearifan Lokal dan Iklim Investasi di Kampung Bersejarah. Lokal Wisdom Vol 1 No 1 November 2009.

[16] Puspitasari, Popi; Djunaedi, Achmad; Sudaryono; Ahimsaputra, Heddy Shri. (2012). Cyclical Changes of Space: The Phenomena of Space Changes in HistoricReligious Kampung Luar Batang, Jakarta, Indonesia. Asian Journal of Environment-Behaviour Studies Vol. 3 Number 9, July 2012. 
